\section{(三) Tallene}

1. Tallene の取报ひ灰

Tallene はドラム詰めカタンクカーー゙輸揆す る。 $250^{\circ} \mathrm{F}$ に熱すると粘度は600 (Seconds Saybolt Universal) に落ちるので、ポンプー゙吸み出 すことが出來、取报ひは便利である。

貯藏タンクにはヒーターとポンプを設诵するを 要す。必要に應じ熱してタンクの内容物に、流動 性を持它す上都分よく行く。

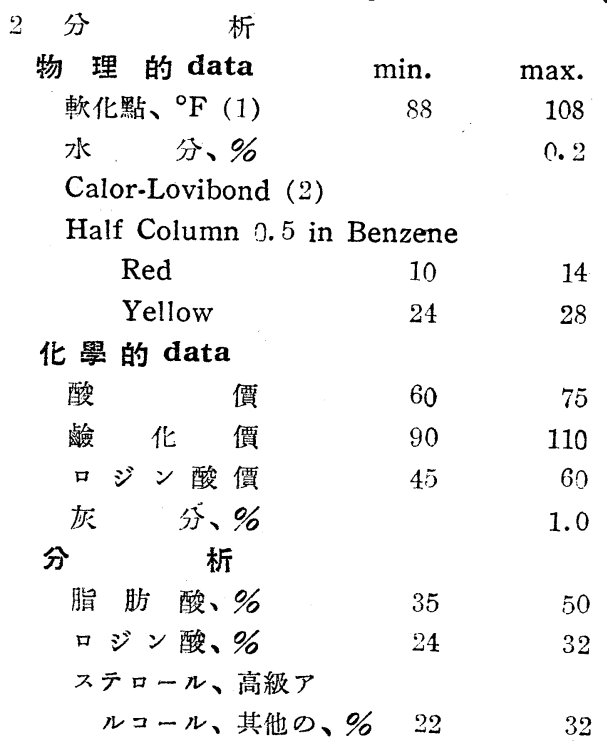

(1) Method of ASTM E28-42T

(2) Using $0.5 \%$ instead of $5 \%$ solution in Benzene

3 Tallene の用途

靴のから゙とのセメント、バインダー、リノリュ ームゃアスフアルトタイルのセメントに利用する

Tallene は贋アスフアルトと混ぜて用弓。

Talleneは可塑劑上軟化劑として有用である。 滑劑的性質はゴムの可塑劑、保護膜及び他の可塑 物に Tallene が用ひられる。

Talleneは簽化され、ェステル化され、石灰化 され、空氣を吹达安れたりして、塗料油、塗料乾 燥劑サイジング、油ェマルジョン滑劑其他に加え される。Liqro の場合と同樣だある。

$\mathrm{NaOH}$ の所要量は酸僠により異る。

\begin{tabular}{lr} 
酸 & $60-75$ \\
$\mathrm{NaOH}$ & \multicolumn{1}{c}{ lbs/100lbs }
\end{tabular}

特にサイジング紙用として水溶液中で dispersing agent として wax や類似物質の如く Tallene 石䶨はよく disperse する。Rosin size と同樣に 利用出來る。

\section{四、將來の見込}

Pine wood から製紙用パルプ製造ミルの能力を考 へると本年 (1946年) は 5,000,000 tons を超える。 此の生產能力屯數のみ分ら考へて tall oil は 125,000 tons利用しらる厄゙あつたらろと思はれる。パルプ生喾 は增加してるるし又加工工程は改良されつ」あるから 年額 150,000 tons の tall oil の生產を期待すること は理由なしとしない。

若し世界中が油脂の缺乏に直面してるる狀態が續く なら、又油脂の消費が益增すならぼ、米國の工業にと

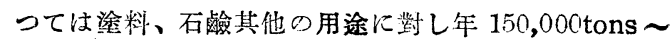
200,000 tons の副產物の脂肪酸を增量する必裂性があ る。

米國石䲓工業は年間凡そ750,000 tons のあらゆる 種類の脂肪、油、脂肪酸を用ふ。塗料、印刷インキ、 リノリニームの種々の工業は年間凡そ 125,000 tons を 用ふ。故に、確實な生產として年 150,000 tons の tall oil を米國として無視すへきでない。

而来韽格は脂肪酸市場儿影響を與へる。

Liqro p Indusoil を消費者が用ひる機會は數ケ條 むる。郎ち

(1) 廉價

（2）供給の安定一Pine wood から pulp 生遮が年 々塯加することによる。

（3）長年月間工業を磪立せんとするのには、信賴 しらべき品質であり、均一性がある。

（4）アメリカ合衆國での全製品に對し高率の課稅 と輸入の義務を避ける。油及脂肪市場に於ける位 置は LiqroとIndusoil は廉貨の脂肪酸としての 注目をひいてるる。

（註）日本では未利用資源であるので出來るだけ詳 細に譯し、紹介するととつした。日本でも此の原 料を㨔むととは可能である。本交のや 5 に分離、 精製してないるのなら現在手に入れるてとは可能

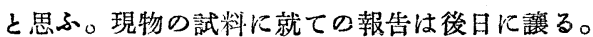

(䇺田)

\title{
ソ連の塗料貶見記
}

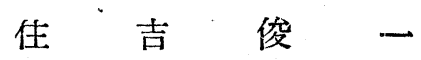

私は2ケ間ソ連チタ區に抑留され最近歸還したもの で、在ソ中の見聞の涩料事情の一端を紹介したいと思
S.

1. 顏料...翰入品が主である版らに思はれた。 
2. 塗粦及び塗裝

（a）油性ペイント 時々町の中で塗つてるるのを 見かける。外部用は夏季數ケ月間しか叙裝出來ない。乾 性油不足のためか割合に塗装されたものが少い。ビル デングの内部、車軹内外部、橋梁等は油性ペイントで 浨られてるた。車輛內部は椅子，腰板、天井等總て暗 綠色又は暗褐色に塗装されてるた。私の塗㥄經驗から 見て、乾性油、堅練ペイントは輸入品が多く日本製品 むあつた。硝子用パテがなかつたので白頑料を練つて 造つたこともあつた。貨物自動車の木部及び金屬部は 殆んど油性ペイントで仕上げてあるが、輸入車はラッ カー塗りである。乘用自動車はラッカー塗りである。 ラッカー塗裝工場は町中には卢ると思ふが見かけなか

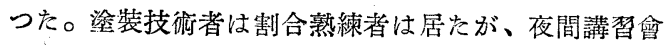

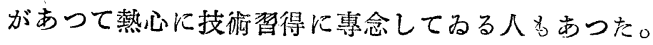

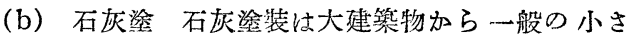
な家屋に至るまで显及されてるて隨時塗装される。外 部內部共に用ひられるが外部は夏季數ヶ月間に限り染 装出萑る。内部ば一年中隨時塗られる。

石灰塗りは先づバィッに水を入れ、塊狀の生石灰を 加一沸䲲が終つてから良く攪挥し、その飽和溶液を用 ひる。刷毛、繩又は纖維を束ねて篣狀にし柄をつけて 塗面をこする。塗布される面は漆喰、未部、金屬部を 問はず艷のないて上、粗面であることなどソ連人は意 としない。一回浢りの後 $3 \sim 4$ 時間してから二回塗り をするのが普通である。濕度の低い國のために此の塗 料で告間に合ひ、塗布後 2-3 ケ月にして少し手につ くゃらになる程度である。外部塗りの際頉料を加へて 調色して用ひることもある。

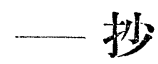

防
火
譯

塗

料

L. S. Birnbaum and M. Markowitz Ind. Eng. chem. 40 (3) 400. 1948

顏料の容量變化、酸化アンチモン及鹽化パラフィン の耐火性に關する研究法と結諭を述べてるる。

最初、電熱使用試驗器に就いて、その配線圖を示め し、次にその操作、試驗法及試驗體等に關して說明し てるる。

基礎研究としての防火淦料組成はアルキツド樹脂、 ペトロリウム・スピリット、ナフテン酸監(鉛、コバル ト、マンガン) からなつてるる、本實驗塗料の顏料組成 は二酸化チタン、チダン・石灰、亞鉛華、硅酸マグネシウ ム、酸化アンチモン及びステアリン酸アルミニウムよ りなり、展色劑としてアルキッド樹脂を使用して、各種
試作叙料を作成してるるが、勿論此の場合酸化アンチ モンを含有するすのと含まないもの二種を試作し、一 方これ等に囕化パラフインを添加しても試みられた。

研究結果を要約すると、酸化アンチモン及有機的結 合鹽素は重要な防火劑である。單獨に酸化アンチモン を耐火劑として使用した時には、乾燥塗膜に於いて、 頋料容曈が $50 \%$ 或はそれ以上で、有機物含有量が少 ない時には、酸化アンチモンは耐火には有效である。 耐火に役立つ有機的結合監素量は、酸化アンチモンの 在否にかかわらず、乾燥塗膜中の有機物の量に關聯す る。

(桝田)

\section{耐アルカリ性 鐵 青}

H. Holtzman. Ind. Eng. chem. 37 (9) 855-861. 1945.

溶性鐵青の製造に於ける一般理論的方法を三つ揚げ 順次各氏法に諭及してるる。

三方法とは、

\begin{tabular}{|c|c|c|}
\hline 方 法 & 鐵毒名 & 反 應 盬 名 \\
\hline $\begin{array}{l}\text { プルツジ } \\
\text { ヤン法 }\end{array}$ & $\mid \begin{array}{l}\text { プルツシ } \\
\text { ヤン型䓯 }\end{array}$ & $\begin{array}{l}\text { フェロシャン化合物と第一鐵監 } \\
\text { の混合 }\end{array}$ \\
\hline $\begin{array}{l}\text { ターンブ } \\
\text { ル法 }\end{array}$ & $\mid \begin{array}{l}\text { ターンブ } \\
\text { ル梨靑 }\end{array}$ & $\begin{array}{l}\text { フェリシャン化合物と第二鐵璺 } \\
\text { の混合 }\end{array}$ \\
\hline 酸 化 法 & 酸化型毒 & 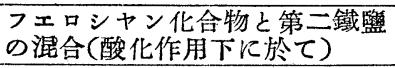 \\
\hline
\end{tabular}

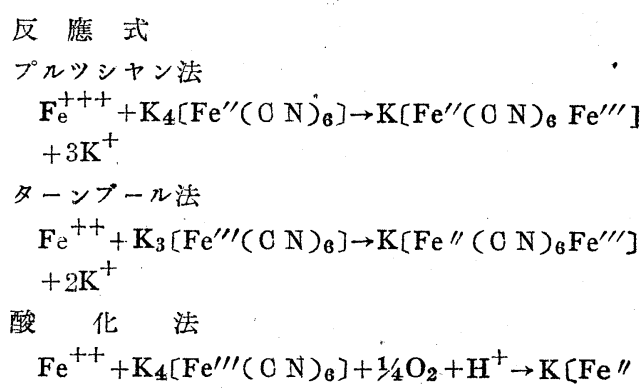

